\title{
Extra-Legal Values in Judicial Interpretation of Law: A Model Reasoning and Few Examples
}

\author{
Leszek Leszczyński ${ }^{1}$
}

Published online: 4 September 2020

(c) The Author(s) 2020

\begin{abstract}
The aim of the paper is to analyze the types of interpretative reasoning determining the content of extra-legal criteria contained in general reference clauses. This construction, despite its normative foundation, detaches itself from the intention of the legislator much more than e.g. the principles of law, at the same time extending deliberately judicial discretion. Extra-legal values, identified by courts as to their type and their content, then confronted with internal legal axiology and concretized with respect to the facts of the case, are the most crucial part of reasoning that affects the process, results and roles of particular rules of judicial interpretation. It reduces the role of language and systemic rules, connecting the effect of determining the content of extra-legal values primarily with the type of political system and the related scope of judicial autonomy. The different impact between democratic and authoritarian regimes on judicial reasoning is confirmed by the analyzed examples of the case law of the European Court of Human Rights and the Polish courts deciding in the period before and after 1989.
\end{abstract}

Keywords General reference clauses · Judicial interpretation of the law · Interpretative reasoning - Determination of the content of extra-legal criteria - Type of political system $\cdot$ Case law examples

The paper has been prepared as a result of the research grant "Axiological Judicial Discretion. Between Legislator's Intentions and Autonomy of Judiciary" (2016/21/B/HS5/00139) financed by the Narodowe Centrum Nauki (National Science Center) in Poland.

Leszek Leszczyński

lex525@wp.pl

1 Chair of the Theory and Philosophy of Law, Institute of Legal Sciences, Faculty of Law and Administration, Maria Curie-Skłodowska University, Lublin, Poland 


\section{Introduction}

References to the criteria of equity, good manners, good faith, social interest, etc., are traditional normative constructions that have been common in the European statutory law orders since the beginning of the nineteenth-century. They appear in the form of general clauses and constitute a kind of legislative opening of the legal system to extra-legal values (undefined in terms of content in legal texts) having mainly the character of social (ethical) values, sometimes acquiring a political or economic attire. Their inclusion in the texts of normative acts causes a relation, important for the content of the law, between the intentions of the legislator who formulates the clauses and the autonomous court which applies the content of these values to the determination of the decision-making process in the light of the facts of the case.

Systematic studies on general clauses, starting with the pioneering work of J. W. Hedemann [11], emphasizing the dangers rather than the benefits resulting from their occurrence in the legal order, focus on particular clauses which are analyzed in the context of specific branches of law. Thus, this theoretical work neither exposes doctrinal approaches, nor enters into polemics with dogmatic legal arrangements. Some of these approaches have been cited as examples and only if they are directly related to the analysis of the issues at hand.

This paper is based on the assumption of the universal nature of determining the axiological content of extra-legal criteria of the clauses in the processes of judicial application of law. In detail, however, differing significantly from typical interpretative reasoning, this determination depends both on the type of values and on the political system in which these processes take place. The aim of the article is to outline a theoretical model of such judicial reasoning in the statutory law order and to link it with the axiological choices within the jurisprudence of different courts. Thus, an appropriately generalized descriptive model is combined with comparative aspects of which the type of a political system plays a crucial role.

The study uses an analytical method aimed at comparative research of selected European normative regulations in which general clauses exist and provides examples of their role in judicial processes. In order to show different ways of determining the content of non-legal criteria applied by the courts, three radically different examples of jurisprudence were selected. One comes from the international law order (jurisprudence of the European Court of Human Rights) while the other two from the national legal order (examples from different periods of application of law in Poland). They illustrate in particular the differences in the use of extra-legal references in autocratic and democratic systems.

The analysis of the main features of judicial reasoning employed in the jurisprudence use of extra-legal criteria is based on four components. The first is an analysis of the general concept of the reference clause and the place of extra-legal values in this normative construction (Sect. 2). The second is an analysis of the autonomous process of judicial determination of the content of extra-legal values (Sect. 3). It includes four detailed kinds of reasoning: (1) identification of the 
elements of the name of the criterion, (2) indication of the moral, political and economic content of the value, (3) confrontation of that content with the legal axiology, and (4) concretization of the extra-legal axiology through its imposition on the established facts of the case. All these components appear in various ways in judicial practice, which is shown, as mentioned above, on the examples of jurisdiction of the two types of courts-international and national (Sect. 4). Finally, in the concluding remarks (Sect. 5), the impact of this reasoning on the roles of the different rules of interpretation and on the scope of judicial discretion is outlined.

\section{Extra-Legal Value as a Component of the General Clause}

(1) The expression "general clause" means an extra-legal reference formulated in a normative text by which the legislator communicates with the addressees of the norms as to the inclusion of these open criteria in decisions on the application of the law [11, p. 9 ff.], [8, p. 6], [15, p. 22-23]. Therefore, being a characteristic construct of the statutory legal orders and thus a part of a legal provision, the general clause is a means of authorizing courts to include appropriately named criteria on the basis of the ruling. This is the case both with the classic clauses contained in European civil law codifications (referring, among others, to such criteria as equity, good faith, good manners, social interest, etc. ${ }^{1}$ ), as well as with the clauses formulated in later, sometimes authoritarian, legal systems (referring, among others, to a healthy national sense, ${ }^{2}$ revolutionary consciousness of the people ${ }^{3}$ or principles of social coexistence ${ }^{4}$ ).

The name of the criterion of the clause refers to either values (e.g., equity) or facts (e.g., customs). The extra-legal character of values means that they are not defined in terms of content in legal regulations, and thus do not form part of the legal axiology. They include, generally speaking, moral, political, or economic values, expressed in various dimensions of generality and concreteness depending on many specific factors determining a given legislative policy. Indication of the name, however, does not determine the specific content of the value. The latter happens in the process of applying the law and depends on, among others, the subject of the

\footnotetext{
${ }^{1}$ Cf. for example criteria of "equity" ("l'equite" in Article 1135 of Code Napoleon, "Billigkeit" in $\S 315$ or $\S 660$ of German BGB or in Article 4 of Swiss ZGB), of "good faith" ("bonne foi" in Article 550 of $\mathrm{CN}$, "Treu und Glauben" in $\S 157$ and $\S 242$ of BGB or Article 2 an 3 of ZGB), or of "good manners" ("les bonnes moeurs" in Article 6 of CN, "gute Sitten" in $\S 26$ of Austrian ABGB or $\S 138$ of BGB.

${ }^{2}$ Cf. German example of Law of 28.06,1935 on Changing the Penal Code (Gesetz zur Änderung des Strafgesetzbuch, Reichsgesetzblatt 1935 I, s. 839) indicating in $\S 2$ of the changed Code criterion "gesundes Volksempfinden", cf. [18], [9: 137 ff.].

${ }^{3}$ See Soviet example of Article 5 of the Decree of the Council of Peoples' Commisioners in Soviet Russia of 24.11.1917, referring to the revolutionary conscience (riewoljucionnoj sowiesti) and revolutionary legal consciousness (riewoljucionnomu prawosoznaniju).

${ }^{4}$ Cf. for example Article 90 of the Constitution of Polish Peoples' Republic of 22.07.1952 imposing duty of the observation of these principles and Article 5 of Polish Civil Code pointing these principles ("zasady wspótzycia spotecznego") as a criterion of the abuse of subjective rights.
} 
judicial process, the type of branch of law, the type of court, but also on the type of political system in which the courts function.

The general clause is a normative construct separate from the principle of law. The latter can be identified with a kind of legal norm, distinguished by above-average hierarchical (location in legal acts of the highest legal significance), axiological (basic values for the whole system or entire branch of law) and functional importance (influence on legal reasoning and the process of interpretation of the law), [24, p. $22 \mathrm{ff}.],[25$, p. 22, $142 \mathrm{ff}$.]. The characteristics of this construction may see their essence in the binding standards according to their fulfillment scheme of "more or less", [7, p. 209 ff.], in their defeasibility, [5, p.77 ff.] cf. optimizing character (defining the highest level of realization of the desired state of affairs), [2, p. 47, 58], finalistic (purposeful) character, [4, p. 40] or in the openness of shaping a generic situation with a closed scope of normalization, [3, p. 6 ff.]. In order to resolve conflicts between the principles of law, a mechanism of balancing, usually correlated with the principle of proportionality, is proposed, [6, p. 27], [1, p. $295 \mathrm{ff}$.$] .$

A functional relationship between clauses and principles can bring extra-legal values and legal values closer together. The proliferation of some forms of reference in legislative and judicial practice (e.g. to good faith, principles of equity) gives the reference its own "essential" meaning for a specific part of legal system, especially if the norm containing such a reference is contained in the central (initial) place of the code regulating the entire branch of law. ${ }^{5}$ Moreover, the general clauses themselves may take into account the double character of the values to which they refer, placing them on a specific "axiological edge" (e.g., in the form of "natürliche Rechtsgrundsatzen" in $\S 7$ of ABGB), allowing both types of values to be weighed in the application of the law process.

(2) Extra-legal values as components of general clauses play various roles in the process of judicial interpretation of the law. Determining the content of these values, both independently and in relation to intra-legal axiology, they must be treated as the most important type of reasoning and interpretation activities in that field. A decision to use the clause in a given decision-making process (validation phase of judicial interpretation) triggers subsequent stages of interpretative reasoning. Firstly, it introduces this content into various relations with arguments set out in legal regulations or earlier court decisions in order to reconstruct the rule, and secondly, it includes this rule in the process of building the final basis for the judicial decision concerning both the qualification of facts of the case and the determination of the consequences (e.g., sanctions) of this qualification.

\footnotetext{
5 As it happened in Swiss ZGB of 1907, referring to extra-legal criteria in Articles 2 and 4 or in $\S 7$ of ABGB (references in both cases deal with the all acts of judicial implementation of all rules of the codes). That creates a situation similar to the role of the criterion of "jori" (interpreted as a social understanding of justice, but also as general principles of law, equity, natural law, natural reason) formulated in Article 3 of the Decree of the Japanese Council of State of 1875 on the Application of Law as the basis for judicial decisions in the absence of written rules and customs (kanshun) cf. [13, p. 775-804], [27, p. 21, 28].
} 


\section{Determination of the Content of Extra-Legal Values: A Model Reasoning}

The process establishing the content of extra-legal criteria in judicial decision-making processes involves four types of reasoning, which are not arranged in precisely defined phases, but which nevertheless reflect their approximate order of precedence. The first is to identify the type of extra-legal value, the second is to determine its content, the third is to compare this content with the fundamental legal axiology, and the fourth is to link the value with a specific decision-making process.

(1) The judicial identification of the type of value is connected with the legislatively expressed name of the extra-legal criterion. It usually includes two (sometimes three) optional components in one name. The first one defines the form of norms or values (e.g., principles, rules, interest, good), the second one-the axiological formula (e.g., justice, equity, co-existence) while the third one-the sphere of social reality, on the basis of which the interpreter identifies the content of the criterion (e.g. moral, social, public, state, citizens', etc.). The latter factor leads to the main indication of the type of value, focused around the choice of moral, political, and economic axiology. Sometimes there is a fourth component, the essence of which is axiological grading of the occurrence of given values or norms (e.g., "good" in connection with "manners" or "legitimate" in relation to "interests").

(2) The determination of the content of the extra-legal value refers to all these components of the criterion name. Even if it refers to a formal (legislative) name of criterion, it usually dissociates from the intention of the legislator in the context of a judicial determination of its content. The extent of this dissociation depends not only on the facts of the case, but also on the political system in which the content is determined by the courts. The latter is alternatively connected with either independence or a certain degree of dependence (measured by the intensity of authoritarianism), which determines the scope of judicial autonomy also when determining the content of extra-legal values.

The reasoning is relatively clear in the case of determination of the content of political values, which always have a general dimension. How they are applied is highly dependent on the type of political regime. In authoritarian systems, the determination of their content, sometimes also in private law, can be based on political or ideological documents (programs, plans, declarations, etc.). The political impact can be based, which means a "hidden" influence, on the guidelines of the politically controlled court of the highest instance ${ }^{6}$ but also, which means breaking all the demands of the rule of law, can be directly influenced by the "manual" imposition of current political content. A rebours, these criteria do not play a significant independent role in the democratic order, tying references to public interest or the public order with the socially justified values.

Establishing the content of economic criteria also depends strongly on the type of political regime and the economic system usually correlated with it. In the system of

\footnotetext{
${ }^{6}$ As was the case with the guidelines on interpretation and application of law issued by Polish Supreme Court law until 1990.
} 
centrally managed (planned) economy, it is possible to politicize the content of these values already at the stage of formulating the name of the criterion and then to take openly into account the state perspective and to refer to political documents (e.g., political aspects of economic plans) in the application of law processes. In the market economy system, on the other hand, it is becoming common for this content to be associated with market rules (e.g., on the grounds of "Regeln einer ordnungsmassigen Wirtschaft" in $\S 1036$ or 1135 of BGB), which may also gain a moral context (e.g. in the case of determining the content of the principles of trade honesty or good trade practices).

The most complex is the process of determining the content of moral values. There are several reasons for this, the most important of which seem to be the factors like: less precise names of the criteria formulated here, diversity of reference points of moral values and norms (all-human, social, group or individual dimensions), the possibility for these values to enter into relations with political and economic values, as well as the difficulty in reading social preferences during the decision-making process, on the basis of which the content of these criteria should be determined. The type of political system that influences the autonomy of the judiciary in determining the content of extra-legal criteria is important here as well, but, even in authoritarian systems, the influence is lesser than in the case of political and economic values, inter alia because of the more dispersed sources of the formation of moral values and their greater diversity. The latter may direct judge to linking the content of values with their universal, as it were, human dimension, going beyond the values of a given society (e.g., natural values or Christian values ${ }^{7}$ ). It may however as well lead to the establishment of moral axiology at the level of a given society (social interest), as involve the discovery of group axiology (e.g., corporate values) and individual axiology (in a categorial sense, e.g. the good of the child, the interest of the taxpayer). In each of these cases, the determination of axiological content requires the use of judicial intuition, however in certain situations, it is not excluded to use documents, regardless of the dimension of axiology (both in the case of Christian values and corporate values, which determine e.g., disciplinary responsibility). The judicial experience and axiological intuition seem to be especially important in the case of values presented in the individual dimension. On the contrary, in the case of moral values presented in the general social dimension, it is the greatest probability of approaching political content. It is in this case that the type of political system and the resulting situation in terms of judicial independence may be a stimulus or an obstacle to the proper reading of the moral (social) axiology.

As can be seen, the most significant influence on the determination of the content of extra-legal values has the independence of the judiciary (or lack thereof), resulting from the type of political system. In the authoritarian type, the legislator himself, counting on the subordination of judiciary, may limit the judge's axiological choices already by the names of the criteria (the scope of freedom of an independent

\footnotetext{
7 Reference to the Christian values appears in Article 18 of the Polish Law on Radio and Television Broadcasting of 29.12.1992 ("Broadcasts or other communications should respect the religious beliefs of the audience, especially the Christian system of values").
} 
court in determining the content of such criterion like "political system established by worker-peasant authority leading to the communist system" 8 is illusory). This mainly concerns political values and politicized economic values (the principle of a planned economy), although it is not completely irrelevant in the case of moral values (social interest, social and economic goal, etc.).

Irrespective of the type of political system, the content of applied extra-legal values is also influenced by a situation of social change, the effects of which may be manifested in case law. However, they depend on the scale and direction of this change. For example, the pro-democratic deep social and legal change (e.g., in Poland after 1989) triggered a case-law anticipation of new, emerging axiology of democratic society without changing legal regulations or names of extra-legal criteria. This applies especially to the determination of the content of all-social criteria (e.g. rules of social coexistence) most exposed to the previous politicization of their content. Pro-authoritarian change has the opposite effect, although in this case the judiciary, shaped on the previously functioning principle of its independence, maintains (at least for some time) the potential to continue practices related to the socially accepted axiology shaped by the democratic system and the rule of law principle.

Of course, the operation of both above mentioned factors of the social environment of law should also be considered in the light of many other features, among others, on the kind of branch of law in which extra-legal criteria function as an element of a clause (the presence of clauses in public law strengthens all effects resulting from the type of political system) or the type of application of law (the same effect is caused by the application of law by administrative bodies).

(3) The third component of the process of determining the final content of an extra-legal criterion is the confrontation of the already established content of such a criterion with legal axiology. This, in turn, may be expressed primarily by the principles of law [24, p. 18 ff.], [6, p. 26, 38, 41-42], [23, p. 160-165], but also may be shaped by the lines of jurisprudence and precedential practice.

The first form of "juridization" of the content of extra-legal criteria consists of juxtaposing it with the content of legal principles. In the context of the role of the legal principles constituting the framework for establishing extra-legal axiology, the relationship between clauses and principles, as mentioned earlier, returns, now not in the light of structural but functional factors. It results from the legislative intention of forming the point-oriented (not completely open) references in the general clauses as well as from the role of the principle of the rule of law, requiring courts to base their decision-making process on law (as competence, procedural and substantial bases of judgment). This proves that there is no general conflict between the determination of the content of extra-legal criteria and the rule of law, despite various detailed relations, which depend primarily on the type of political system.

Speaking generally, the established content of extra-legal values cannot break the content of the basic principles of law. This is particularly true in the case of

\footnotetext{
${ }^{8}$ See Article 6 of the Soviet Criminal Code of 26.02.1926 (C3, 1926, No. 9, 71).
} 
constitutional principles, ${ }^{9}$ although it also plays an essential role in the case of principles of basic branches of law. The power of influence of legal axiology is, however, related to the type of principles. It may involve not only the principles normatively expressed in a given system of regulation (which in the authoritarian system may politicize the extra-legal axiolog $\mathrm{y}^{10}$ ), but also the rules shaped "only" in the "cultural tradition", which influence on extra-legal axiology can be described as strong only in the case of the democratic political system. In both situations, the confrontation of general clauses with legal principles means the formation of a specific "axiological edge", allowing courts to move on the border of both types of axiology and to take them into account in different proportions, depending on various factors, including the needs of a given decision-making process.

The second form of comparing the juridical and extra-legal criteria is related to the fact that courts in the course of actual decision-making processes refer to their content already established in previous jurisprudence. It does not depend on the type of political system as much as it does in other elements of determining the content of extra-legal criteria. Here, the type of legal culture, within which the jurisprudence plays a greater or lesser role in the current decision-making processes, is much more influential. The reference consists of the use of earlier court decisions (individual decisions or jurisdictional lines) in which the content of value was determined and then disclosed in its justification, [16, p. 1-14]. That method operates softer than using the formulated normative principles of law. It ties however effectively extralegal content with the judicial discourse created by the court, taking into account the fact that the use of the case law also in legal systems, where there is no regular precedential practice, is stronger and stronger, [17, p. $3 \mathrm{ff}$.]. As a result, we are approaching the socially important value of the uniformity of judicial application of law, which is particularly difficult to achieve in terms of determining the content of extra-legal criteria.

(4) Finally, the fourth component of the process of determining the content of the extra-legal criterion is the concretization (a kind of "contextualization") of extra-legal axiology. The importance of this relation results from the fact that the determination of the content of the criteria is not made for cognitive or declaratory purposes, but for practical ones. It is supposed to serve the purpose of making a court decision in the context of facts of the case and other properties of the so-called materials of the court case. In certain situations (this applies especially to moral values) it may mean referring to axiology accepted by the judicial environment (e.g. the community of judges, both general and of the same court) or even a certain scope of "personalization" of this axiology, which may to some extent (narrower, however,

\footnotetext{
9 The principle of law might be confronted with the extra-legal criterion directly, as it happens in Article 2 of the Constitution of the Republic of Poland of 2 April 1997 forming a provision ("The Republic of Poland is a democratic rule-of-law state, implementing the principles of social justice.") potentially confronting both types of axiology and leading to various relations, cf. [22, p. 147-175].

10 If, for example, according to (derogated in 1990) Article 4 of Polish Civil Code, all legal regulations (i.e. also those that contain extra-legal references) are to be interpreted in accordance with the principles of the political system and the goals of the state.
} 
than in the Anglo-Saxon equity law) modify the content established on the basis of the previously indicated actions.

\section{Examples of Judicial Practice}

The outlined theoretical model of interpretative reasoning related to the determination of the content of extra-legal values expressed in general reference clauses finds its fulfillment in judicial practice. The type of political (and in a sense economic) system and the situation of profound social and legal change presented above are the factors that have the strongest impact on judicial practice, primarily because of their impact on the scope of judicial autonomy. In this context, the content and role of extra-legal axiology in the processes of application of the law, in addition to properties of legal culture (distinguishing the order of statutory law from e.g., common law) is also affected by the type of branch of law applied, the type of implementation of law (distinguishing its court-type from administrative or mediation decision making), the kind of court making a decision and its hierarchical location (with a special role of the highest instance courts) or the type of court decision (with a separate position of resolutions of extended panels in the highest instance courts).

The lack of space in this paper to indicate the wide range of case law taking into account the role of these factors makes it necessary to select a few examples of judicial practice relating to sufficiently diverse criteria and interpretative situations. This can be achieved by signalization of the achievements of the European Court of Human Rights in the context of the criterion of "necessity in a democratic society" and the jurisprudence of Polish courts, ruling at the turn of the democratic legal change of 1989 (on the one hand, cutting off from the earlier guidelines of the Supreme Court, and on the other hand-establishing different relation between the criteria of the social interest and the legitimate interest of citizens). Even if it does not reflect the complexity of the judicial practices, it allows to illustrate the operation of several factors influencing the manner and outcome of determining the content of the extra-legal criterion.

(1) The European Convention for the Protection of Human Rights and Fundamental Freedoms, by regulating matters strongly "soaked" with axiology, does not waive the right of both the courts of the member states of the Council of Europe and the European Court of Human Rights (ECtHR) to use in their judgements criteria which additionally open the normative regulation of the Convention in axiological terms. The most important role in this context is played by the criterion of "necessity in a democratic society", [10, pp. 283-301], which refers to the social axiology (democratic society) seen pragmatically (necessity) and intentionally (connection with other criteria defining the aim of a Member State's action, which consists in limiting the scope of right formulated in paragraph 1 of the provisions of Articles 8, 9, 10, 11 of the Convention and Article 2 of Protocol No. 4). The clause therefore refers to a standard, understood as a value, the scope of protection of which depends on the assessment of the purpose and manner of state interference in the content of a given right. The Court has repeatedly specified the content of the standard as a whole. With regard to the criterion of a "democratic society", it stressed 
the presence, first and foremost, of the values of pluralism and tolerance. ${ }^{11}$ The term "necessary" is clearly distinguished from the term "indispensable", "desirable", "admissible" or "reasonable". ${ }^{12}$ In addition, the scope of the necessity test is nuanced depending on the type of law or even the type of good protected by the law. ${ }^{13}$ Important for the application of the standard is its imposition on a specific (usually axiologically involved) purpose of the interference (e.g., interest of national security, public safety, economic well-being, protection of morals, public order), which may justify it when the state's interference itself, being provided for by law, ${ }^{14}$ results from an urgent need and is based on proportional means of action. This is a situation in which the limits of necessity, "measured" in each case in the context of a specific legal situation, are not exceeded. ${ }^{15}$

The set of extra-legal criteria shaped in this way creates a wide discretion of the courts, both national and ECtHR, which decide on their basis. Axiological content can be distinguished at the level of particular societies and states, ${ }^{16}$ but it also has a universal dimension, visible in the case law of the ECtHR, ${ }^{17}$ which is subsequently adopted by the courts of the Member States. Functional relations between the criteria that the Court has developed are determined by the order in which they are taken into account, considering the specific features of the case and type of protected axiological content. They have mainly a social (moral) character, but they do not avoid political aspects, especially where the criteria of interest of state security or public order are involved. The latter ones are treated however pragmatically (not ideologically) and understood in a climate appropriate to the democratic and the rule of law systems of the member states of the Council of Europe.

(2) Examples drawn from the Polish judicial practice are also characteristic, especially if they are included in the distinction between the period before and after 1989. The first one concerns the negation in 1992 of the role of the Polish Supreme Court (SC) guidelines issued before that year, and the second one-two different ways of establishing relations between non-legal criteria.

\footnotetext{
11 Cf. e.g. $\S 49$ of judgement Handyside v. United Kingdom of 7.12.1976, A.24), or $\S 42$ of judgement Bowman v. United Kingdom of 19.02.1998 (RJD 1998-J).

12 "The Court notes at this juncture that, whilst the adjective "necessary", within the meaning of Article $10 \S 2$, is not synonymous with "indispensable" (...) neither has it the flexibility of such expressions as "admissible" (...), "ordinary" (...), "useful" (...), "reasonable" (...) or "desirable" (Handyside v. United Kingdom of 7.12.1976, A.24).

13 Cf. e.g. Barthold v. Germany of 31.01.1986 (A.98) where the Court held that the assessment of the need to interfere in a commercial statement is less restrictive than that of political or artistic statements.

14 this condition is also more universal than just a formal definition of interference by national law, referring to the not indifferent axiologically standards of the rule of law common to the member states of the Council of Europe (e.g. § 49 Halford v. United Kingdom, 25.06.1997, RJD 1997-III).

15 Cf. e.g. § 52 of judgement Vogt v. Germany (26.09.1995, A. 323), judgement The Sunday Times v. United Kingdom (No. 2) of 26.11.1991 (A.217), Dudgeon v. United Kingdom (22.10.1981, A.45) defining this relationship with regard to, among others, protection of morals or $\S 55$ of Zana v. Turkey (25.11.1997, RJD 1997-V) defining this relationship in the context of protection of the public order.

16 Cf. judgement Otto Preminger v Austria of 20.08 .1994 (A.295), § 48 of judgement Handyside v. United Kingdom, 7.12.1976, A.24, § 77 of Great Chamber ruling in the case of Evans v. United Kingdom, 10.04.2007 (6339/05), § 55 Zana v. Turkey, 25.11.1997 (RJD 1997-V).

17 Cf. e.g. $\S 49$ of Halford v. United Kingdom of 25.06.1997 (RJD 1997-III).
} 
The guidelines on the interpretation and application of the law, which were functioning between 1949 and $1989,{ }^{18}$ were issued by the SC and had an abstract character (not related, for example, to the cassation of a specific judgment) and binding force (as they could have been the basis for the cassation) in the field of civil, criminal or labor law. They were mainly related to the function of the unification of court jurisdiction, which could also include directives on determining the content of particular extra-legal criteria. That, particularly in certain periods of law functioning in Poland before 1989 (especially in 1952-55 and 1981-82) meant, in the absence of real independence of the SC and the entire judiciary, political control of this content. Adoption in 1992 by the SC in Full Composition ${ }^{19}$ of the resolution on the loss of binding force of guidelines formulated by this Court before 1989 gave clearly primacy to the independence of the judiciary over the value of uniformity of jurisprudence resulting from the functioning of the guidelines. ${ }^{20}$ It meant not only the lack of obligation to apply them, but also the possibility for courts to establish new content of extra-legal criteria, different from those adopted in the guidelines and indirectly in decisions based on them. ${ }^{21}$ However, the resolution did not result in a general revision of the content of the criteria shaped before, despite the gradual de-politicization of the content of some criteria, especially in the understanding of the current political objectives. ${ }^{22}$ This also applies to the most frequently used reference in civil and labor law to "the principles of social coexistence", which, although they received more individualized moral content, using not only all-social axiology but also group-oriented or individualized axiology, ${ }^{23}$ were by no means denied or replaced by other criteria. This was dominated by the conviction, also expressed earlier, that they could be used as a juncture with the tradition of European equity jurisdiction. ${ }^{24}$ The maintenance of this conviction contributed, among others, to the maintenance of "old" clause referring to the principles of social coexistence during the amendments of the Polish Civil Code after $1989 .{ }^{25}$

\footnotetext{
18 The guidelines were not issued since the beginning of 1990, as a result of Article 3(9) of the Act of 20 December 1989 amending the Acts-Law on the system of common courts, on the Supreme Court, on the Supreme Administrative Court, on the Constitutional Tribunal, on the system of military courts and on the notary public (Journal of Laws, No. 73, item 436).

${ }^{19}$ Kw. Pr 5/92 of 5.05.1992, OSNKW 1993, item 1.

${ }^{20}$ The resolution stated in this context that "... the guidelines were the result of re-evaluation of concepts about the basic functions of the Supreme Court and resulted from such axiological principles in which the uniformity of jurisprudence was to have an independent value, or even superior to the administration of justice". (p. 10).

${ }^{21}$ Some of the guidelines politicized moral criteria, cf. e.g. the resolution of the Civil Chamber of the Supreme Court of 15.12.1969, III CZP 12/69).

22 E.g., resolution of the Supreme Court of 27.07.1990, I PRN 28/90, OSNAPiUS 1991, item 112 or judgement of the Supreme Court of 22.08.1991, III ARN 26/91, OSP 1993, item 4.

${ }^{23}$ E.g., judgement of the Supreme Court 12.01.1998, I PKN 458/97, OSNAPiUS 1998, item 655, judgement of the Supreme Court of 19.01.1998, I CKN 424/97, OSNIC 1998, item 136.

${ }^{24}$ E.g., judgement of the Supreme Court of 20.05.1997, II CKN 172/97, OSNIC 1997, item 196.

25 The old ("socialist") clause referring to the principles of social coexistence remain a criterion in over 20 provisions of this Code. Nevertheless, in the case of newest amendments to the provisions of the Civil Code, the legislator refers already to the classic criteria of "principles of equity" e.g. in Article 761(2) or of "good manners" e.g. in Article $72 \S 2$ or Article 385(2).
} 
The second Polish example is related to judicial control of the application of administrative law. The Polish Code of Administrative Procedure, adopted in 1960 (still in force, although amended many times), formulates in Article 7 a general principle for administrative bodies concerning each process of making decisions, which reads as follows: "In the course of proceedings, public administration bodies shall uphold the rule of law and shall take ex officio or at the request of the parties all actions necessary to clarify the facts of the case in detail and to settle the case, taking into account the social interest and the legitimate interest of citizens". It, therefore, formulates two extra-legal criteria with different points of reference for their axiology (social interest and the interest of a citizens that, however, requires to be qualified as legitimate), additionally imposing the decision-making role of both criteria on the obligation to act in accordance with the principle of the rule of law. Thus, there is room for a potential collision between the social and individual dimensions of interest and between extra-legal and intra-legal (principle of the rule of law) axiology. Within this first "clash", one can notice two completely different positions of the judiciary, formulated in the different political environment of the judicial review of administrative actions. In 1981, the Supreme Administrative Court defined this relationship in the following terms: "The content of Article 7 of the Code (...) means that the scope of protection of a legitimate individual interest reaches the limits of the collision with the social interest, which is the overriding value in a socialist state". ${ }^{26}$ The social and legal change that has taken place since 1989 has radically changed this perspective, and its milestone was the Supreme Court judgment of 1993, which defined this relationship in the same normative state as follows: “...in the lawful state there is no place for mechanically and rigidly understood principle of the primacy of general interest over individual interest (...), in each case the administrative authority is obliged to indicate what general (public) interest is at stake and prove that it is so important and significant that it absolutely requires the limitation of individual rights of citizens. Both the existence of such interest and its importance, as well as the reasons for the need to prioritize the public interest over the individual in a specific case, must always be subject to close control of higher administrative organ and of judicial review". ${ }^{27}$ So far, it is the latter judgment (despite the use of the term "public interest" instead of the term "social interest" used in the Code), being the result of the adaptation of the democratic-liberal perspective, specifies the way in which the two values are weighted in the decisionmaking practice of the administrative authorities. It also starts the jurisdictional line of administrative courts dealing with the control of that weighting (which is not an easy task in a situation where it is assumed that this control consists of examining the administration's activity from the point of view of "legality").

Both examples of the jurisprudence of Polish courts indicate the dependence of the practice of determining the content of open criteria on the type of social and political environment of law, whose features are particularly evident in the situation of profound social and legal change. The same names of criteria lead to the variety

26 Judgement of 11.06.1981, SA 820/81, OSPiKA 1982, item 22.

27 Judgement of 18.11.1993, III ARN 49/93, OSNIC 1994, item 181. 
of their axiological content due to the change in social environment of law. Against this background, the case-law of the ECtHR, based on fixed values, is so stable that we can only speak of a natural evolution in the perspective of almost 70 years of the Convention's operation. All these examples prove, that the open criteria work for politicization of the law in autocracies and for "socialization" of the legal order in democracies.

\section{Concluding Remarks}

The aforementioned case law examples might also be seen in the light of changes in the role of particular rules of interpretation in the process of determining the content of the extra-legal criterion (in comparison with the general model of interpretation). An important change deals with the limitation of the role of language and systemic rules. Of course, it is not indifferent what words are used in legislative regulation, but it is not the linguistic layer that determines the content of the criterion assigned to a given name. Similarly, it is not indifferent, where in the system of regulation the clause is located (especially in the context of the position of the "meta-clauses", influencing the content of other criteria ${ }^{28}$ or connection of some clauses with the principles of law, defining the content and scope of the "axiological edge" between the intra- and extra-legal axiology, [23, p. $160 \mathrm{ff}$.]), but it is not the structure of regulation that determines the content of the value. The interpretation of the clause is about determining the axiological framework in which the normative formula (e.g., moral norm) is used to construct the basis for the judicial decision. As a result of that, rules of interpretation referring to extra-legal axiology being taken into account from the very beginning of this reasoning, define its outcome, even, if the role of some functional rules must be noticed (when the nature of the identified value indicates pragmatic aspects of its content, e.g. the principle of rational economy, social and economic goal).

Although the participation of extra-legal axiology in the judicial interpretation of the law is determined by every element of this process, it is realized to the greatest extent in the determination of the content of the extra-legal value. Like any other interpretative reasoning, it takes place under conditions of judicial discretion, sometimes reaching the point of judicial activism, [12], [20, p. $47 \mathrm{ff}$.]. The appearance of general clauses further extends the scope of that discretion, being an immanent and irremovable feature of any process of applying the law (resulted e.g., from properties of legal language or the relationship between the moment of creating a rule and the changing social environment of law). That is why, the clauses enlarging its scale in a precise and legislative manner (in contrast to the Roman ius aequitas, [14, p. 334-336] or Anglo-American equity law, [19], [21], [26], which are formed as

\footnotetext{
${ }^{28}$ In the current Polish legal system the meta-clauses are formed in Article 2 of the Constitution of the Republic of Poland (principles of social justice), Article 7 of the Code of Administrative Procedure (social interest and legitimate interest of the citizens), art. 5, art. 58 or art. 65 of the Civil Code (rules of social coexistence, social and economic goal of the law).
} 
independent of official case-law), do not strengthen legislative control over this reasoning, the scope of which is limited if not illusory, especially if the processes of application of law are carried out by independent courts.

The freedom associated with, inter alia, the proportion of use of the various rules of interpretation is reflected in each of the four previously perceived aspects of determining the content of the extra-legal criterion. The "wisdom" of judicial application of law processes, even if they show great autonomy in relation to specific legislative intentions, should not, however, make it possible to dissociate oneself from the objectivized dimension of this content. This is served primarily by the confrontation of established extra-legal content with intra-legal values (resulting from both the principles of law and permanent achievements of jurisprudence) and by grounding of this content in the properties of a specific decision-making process and established facts of the case. That should work against arbitralization, instrumentalization, politicization, and strong personalization of this segment of judicial interpretation, what would indicate the serious abuse of such discretion, especially dangerous in the authoritarian political systems. It should be remembered that while in a democratic system the chances of socializing the law prevail if the effect of the clauses is considered, in an authoritarian system, the extra-legal references create a danger of politicizing not only their content but also the entire legal order.

Open Access This article is licensed under a Creative Commons Attribution 4.0 International License, which permits use, sharing, adaptation, distribution and reproduction in any medium or format, as long as you give appropriate credit to the original author(s) and the source, provide a link to the Creative Commons licence, and indicate if changes were made. The images or other third party material in this article are included in the article's Creative Commons licence, unless indicated otherwise in a credit line to the material. If material is not included in the article's Creative Commons licence and your intended use is not permitted by statutory regulation or exceeds the permitted use, you will need to obtain permission directly from the copyright holder. To view a copy of this licence, visit http://creativecommons.org/ licenses/by/4.0/.

\section{References}

1. Alexy, Robert. 2000. On the Structure of Legal Principles. Ratio Iuris 3: 294-304.

2. Alexy, Robert. 2002. A Theory of Constitutional Rights. Oxford: Oxford University Press.

3. Atienza, Manuel, and Juan R. Manero. 1999. A Theory of Legal Sentences. Dordrecht: Springer Netherlands.

4. Avila, Humberto. 2007. Theory of Legal Principles. Dordrecht: Springer Netherlands.

5. Bäcker, Carsten. 2010. Rules, Principles, and Defeasibility. Archiv für Rechts- und Sozialphilosophie 119: 79-91.

6. Dworkin, Ronald. 1967. The Model of Rules. University of Chicago Law Review 35: 14-46.

7. Dworkin, Ronald. 1990. Law's Empire. London: Fontana Press.

8. Esser, Josef. 1979. Juristisches Argumentieren in Wanzeln des Rechtsfindungkonzept unseres Jahrhunderts. Heidelberg: Der Universitätsverlag Winter.

9. Haftl, Benedict. 2000. Das nationalistische Willenstrafrecht. Berlin: Weissensee Verlag.

10. Harris, David, Michael O'Boyle, and Chris Warbrick. 1985. Law of the European Convention on Human Rights. London: Butterworths.

11. Hedemann, Justus W. 1933. Die Flucht in die Generalklauseln. Eine Gefahr für Recht und Staat. Tübingen: J.C.B. Mohr.

12. Hoffmaster, Barry. 1982. Understanding Judicial Discretion. Law and Philosophy 1: 21-55. 
13. Itoh, Hiroshi. 1970. How Judges Think in Japan. The American Journal of Comparative Law 18: 775-804.

14. Kaser, Max. 1975. Das Römische Privatrecht. Die Nachklassischen Entwicklungen. München: C.H. Beck.

15. Leszczyński, Leszek. 2000. Tworzenie generalnych klauzul odsyłajacych. Kraków: Zakamycze.

16. Leszczyński, Leszek. 2020. Implementing Prior Judicial Decisions as Precedents: The Context of Application and Justification. International Journal for the Semiotics of Law 33: 231-244. https:// doi.org/10.1007/s11196-019-09674-9.

17. MacCormick, Neil D., and Robert S. Summers. 1998. Introducation. In Interpreting Precedent. A Comparative Study, ed. Neil D. MacCormick and Robert S. Summers, 1-15. Dartmouth: Ashgate.

18. Majer, Diemut. 1987. Grundlagen der nationalistichen Rechtssystems: Führerprinzip, Sonderrecht, Einheitspartei. Stuttgart: Kohlhammer.

19. Martin, Jill E., and Harold G. Hanbury. 1993. Modern Equity. London: Sweel \& Maxwell.

20. Morawski, Lech. 2004. Stressing-The Controversy Between Judicial Pasivism and Activism. In Stressing Legal Decisions, ed. Tadeusz Biernat, Krzysztof Pałecki, Aleksander Peczenik, Christoffer Wong, and Marek Zirk-Sadowski, 47-61. Kraków: Polpress. PL Publishers.

21. Rümelin, Max. 1921. Die Billigkeit im Recht. Tübingen: Mohr Siebeck.

22. Tkacz, Sławomir. 2003. Rozumienie sprawiedliwości w orzecznictwie Trybunału Konstytucyjnego. Katowice: Wydawnictwo Uniwersytetu Śląskiego.

23. Van Hoecke, Mark. 2002. Law as Communication. Oxford: Hart Publishing.

24. Wróblewski, Jerzy. 1965. Prawo obowiązujące a "ogólne zasady prawa". Zeszyty Naukowe Uniwersytetu Łódzkiego, Nauki Humanistyczno-Społeczne, Seria I 42: 17-38.

25. Wronkowska, Sławomira, Maciej Zieliński, and Zygmunt Ziembiński. 1974. Zasady prawa. Zagadnienia Podstawowe. Warszawa: Wydawnictwo Prawnicze.

26. Yntema, Hessel E. 1967. Equity in Civil and Common Law. American Journal of Comparative Law 16(1-2): 60-86.

27. Young, Michael K. 1986. The Japanese Legal System, History and Structure. In Doing Business in Japan, ed. Zentaro Kitagawa, 1-45. New York: Matthew Bender.

Publisher's Note Springer Nature remains neutral with regard to jurisdictional claims in published maps and institutional affiliations. 